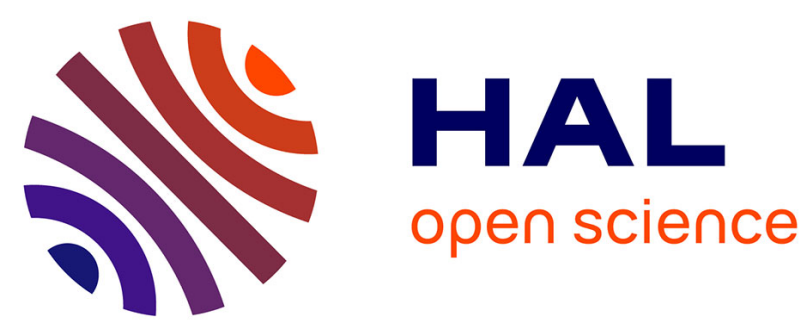

\title{
Local electrochemical investigation of copper patina
}

M.M. Mennucci, M. Sanchez-Moreno, I.V. Aoki, Marie-Claude Bernard,

Hercilio G. de Melo, Suzanne Joiret, Vincent Vivier

\section{To cite this version:}

M.M. Mennucci, M. Sanchez-Moreno, I.V. Aoki, Marie-Claude Bernard, Hercilio G. de Melo, et al.. Local electrochemical investigation of copper patina. Journal of Solid State Electrochemistry, 2012, 16 (1), pp.109-116. 10.1007/s10008-010-1290-7 . hal-00777483

\section{HAL Id: hal-00777483 \\ https://hal.sorbonne-universite.fr/hal-00777483}

Submitted on 8 Feb 2016

HAL is a multi-disciplinary open access archive for the deposit and dissemination of scientific research documents, whether they are published or not. The documents may come from teaching and research institutions in France or abroad, or from public or private research centers.
L'archive ouverte pluridisciplinaire HAL, est destinée au dépôt et à la diffusion de documents scientifiques de niveau recherche, publiés ou non, émanant des établissements d'enseignement et de recherche français ou étrangers, des laboratoires publics ou privés. 


\section{Local electrochemical investigation of copper patina}

M. M. Mennucci, ${ }^{\mathrm{a}, \mathrm{b}, \mathrm{c}}$ M. Sanchez-Moreno, ${ }^{\mathrm{a}, \mathrm{b}, \mathrm{d},{ }^{*}}$ I. V. Aoki, ${ }^{\mathrm{c}}$ M-C. Bernard, ${ }^{\mathrm{a}, \mathrm{b}}$ H. G. de Melo, ${ }^{c}$ S. Joiret, ${ }^{a, b}$ V. Vivier ${ }^{a, b, *}$

${ }^{a}$ LISE, UPR 15 du CNRS, Université Pierre et Marie Curie, CP 133, 4 Place Jussieu, 75252 Paris Cedex 05 - France

${ }^{b}$ University Pierre et Marie Curie, 4 place Jussieu, 75252 Paris Cedex 05, France

${ }^{c}$ Chemical Engineering Department of the Polytechnic School of the São Paulo University. P.O. Box 61548, CEP: 05424-970 - São Paulo-SP - Brazil

"Institute of Construction Sciences “Eduardo Torroja” (CSIC), C/Serrano Galvache 4, 28033 Madrid, Spain

Corresponding authors: vincent.vivier@upmc.fr (Vincent Vivier)

mercesanc@ietcc.csic.es (Mercedes Sanchez) 


\begin{abstract}
The patination of copper is known for its complexity and heterogeneous formation. For a deeper investigation, a locally resolved surface analysis was considered. An exact determination of the accessed area and a potentiostatic control in a three-electrode configuration was reached with the use of the electrochemical microcell technique, which enables local electrochemical measurement such as local electrochemical impedance spectroscopy (LEIS) and cyclic voltammetry (CV). Such a technique provides a unique way for performing the investigation of heterogeneities on electrode surfaces.

The local electrochemical measurements on the artificially patinated surface have allowed distinguishing areas of different reactivity even when the analysis of the surface revealed a homogenous chemical composition of patina. Local measurements with the electrochemical microcell showed the presence of small defects on the patina layer that can be modelled by considering a hemispherical diffusion process at small active areas surrounded by larger less reactive domains.
\end{abstract}

Keywords: Microcell technique; Local electrochemical impedance spectroscopy; Copper corrosion; Patina, Raman Spectroscopy. 


\section{Introduction}

Historical heritage has attracted much attention for its social and cultural importance [1-6]. However, during the last century, environmental changes have significantly affected the conservation state of the metallic historical heritage exposed to atmosphere leading to increase the degradation promoted by contaminants such as chloride or sulphate ions. This fact deserves special attention in urban atmospheres, where pollutant discharges are especially severe, mainly due to the fact that the major part of the monuments with historical value is located in these cities centres $[7,8]$.

Copper and its alloys are the metals most commonly used to produce monumental metallic artefacts. When these pieces are exposed to non-contaminated atmosphere, a protective layer of corrosion products, commonly called "patina", spontaneously forms on their surface, acting as a barrier and preventing fast corrosion of the object. Therefore, monuments exposed for long periods to "normal" atmospheric conditions are coated with patina layers, and, in this particular case, the metal and patina as a whole is the relevant system to be protected [9]. To avoid or to minimize the deterioration of these unique pieces by polluted-atmospheric conditions, it is necessary to understand how pollutants can affect the corrosion behaviour of patinated copper.

Copper patinas are complex structures containing several constituents. Besides corrosion products they also include deposited materials, which together provide their overall appearance. Their major chemical constituents are well known, and originate from elements found in the atmosphere, the most encountered corrosion products being cuprite $\left(\mathrm{Cu}_{2} \mathrm{O}\right)$, copper hydroxy sulphates, namely brochantite $\left(\mathrm{Cu}_{4}(\mathrm{OH})_{6} \mathrm{SO}_{4}\right)$ and antlerite $\left(\mathrm{Cu}_{3}(\mathrm{OH})_{4} \mathrm{SO}_{4}\right)$, and the copper hydroxy chloride dimorphs atacamite and paratacamite $\left(\mathrm{Cu}_{2}(\mathrm{OH})_{3} \mathrm{Cl}\right)$ [10-14]. Electrochemical methods are widely applied in corrosion science, however they are seldom used in the case of the conservation of cultural heritage metallic artefacts, for which the use of 
treatments and analytical techniques are significantly constrained due to the fact that the objects under investigation can be unique, precious or ancient and usually sampling is severely restrained. As a result, each analysis has to be non-destructive and all treatments to be reversible.

Non-destructive electrochemical techniques can allow the characterization of the protective nature of patina layers. Different methods for local electrochemical measurements have been developed during the last decades, distinguishing between scanning techniques such as the scanning electrochemical microscope $[15,16]$ and techniques such as the electrochemical microcell $[17,18]$ where only a small local area is delimitated and in direct contact with the electrolyte. Studies of local corrosion on heterogeneous metal surfaces have been successfully carried out with the electrochemical microcell as this technique allows to delimitate local areas of the samples without affecting the whole surface [19-23]. Thus, the use of local electrochemical techniques to analyze the homogeneity (or the heterogeneity) of this protective layer will be hugely interesting. The possibilities and limitations of these techniques have been reported by different authors [24-26].

In present work local cyclic voltammetry and local electrochemical impedance spectroscopy using a specially designed microcell have been performed to evaluate the effect of sulphate solution on the electrochemical behaviour of copper and artificial patina on copper.

\section{Experimental}

Disk working electrodes cut from copper sheets (purity $99.99 \%$ and $0.89 \mathrm{~cm}$ in thickness) were employed in the present work. Only pure copper was used since it's the main bronze constituent. By this way, data interpretation could have been performed without taking into account any bronze structure heterogeneity in the electrochemical response. The bare electrodes $\left(1 \mathrm{~cm}^{2}\right)$ were embedded by hot resin mounting, sequentially grinded with silicon 
carbide emery paper up to 600 grit and rinsed with deionised water and alcohol prior each experiment.

All solutions were prepared with bi-distilled water and analytical grade chemicals were used as received.

An artificial patina was obtained by immersion of the copper electrodes in a $5 \mathrm{~g} / 1 \mathrm{CuSO}_{4}+6 \mathrm{~g} / 1$ $\mathrm{Na}_{2} \mathrm{SO}_{4}$ solution at $50^{\circ} \mathrm{C}$ during 14 days. The temperature was regulated at $\pm 0.5^{\circ} \mathrm{C}$, and the cell was hermetically closed to avoid the evaporation of the solution and oxygen admission. The resulting product formed a green compact layer on top of copper.

The structural characterization of the patina was carried out by scanning electron microscopy (SEM) and Raman microspectroscopy. SEM observations were performed with a Zeiss ULTRA 55 microscope coupled with EDS elemental semi-quantitative analyses. The Raman microspectroscopy was carried out with a Labram-Jobin-Yvon spectrometer. The samples were irradiated with a He-Ne laser at $\lambda=632.8 \mathrm{~nm}$. The laser power was varied between 0.1 and $1 \mathrm{~mW}$ to avoid any thermal effect on sample during the analyses. A confocal microscope was used and the investigated area was limited to $5 \mu \mathrm{m}^{2}$ using a 80 ULWD objective lens.

The electrochemical characterization of pure (used as reference material) and artificially patinated copper were carried out with an electrochemical microcell arrangement already described in detail elsewhere [27]. Briefly, it consists of a three-electrode arrangement in which a Pt wire of $100 \mu \mathrm{m}$ diameter as counter electrode was located at $1 \mathrm{~cm}$ from the working electrode surface, and a $160 \mu \mathrm{m}$ diameter $\mathrm{Ag}$ wire anodized in $\mathrm{KCl}$ solution [28] was used as reference electrode. A glass capillary of $500 \mu \mathrm{m}$ diameter was used to delimitate the exposed area. A homogeneous silicone gasket was deposited on the open end of the apex of the capillary to ensure a well-reproducible wetted area and to avoid both leakage and evaporation of the electrolyte. The whole electrochemical microcell was fixed to a strain gauge for controlling the force applied by the tip to the sample surface, assuring a constant 
mechanical pressure on the silicone gasket. The electrolyte supply was automated by a syringe pump. The electrolyte filled the capillary providing the ionic connection needed to carry out the electrochemical measurements.

Local electrochemical measurements were performed to characterize the electrochemical behaviour of pure copper and artificial patina in $0.5 \mathrm{M} \mathrm{Na} \mathrm{NO}_{4}$ solutions. Cyclic voltammograms were obtained from -1 to $+0.6 \mathrm{~V}_{\mathrm{SCE}}$ starting from the more cathodic potential to the anodic direction, and the potential scan rate was $100 \mathrm{mVs}^{-1}$.

Local electrochemical impedance spectroscopy (LEIS) was carried out under potentiostatic regulation at the corrosion potential, $E_{\text {corr }}$, with an ac perturbation amplitude of $15 \mathrm{mV}_{\mathrm{rms}}$ in the frequency range between $10 \mathrm{kHz}$ and $100 \mathrm{mHz}$, and with 7 points per decade of frequency. $E_{\text {corr }}$ was measured between each experiment.

The potentiostat was a home-made low-noise apparatus allowing measurements of small currents (large impedance) in the whole frequency range. Both the potential control and the measurements were carried out with an analogical/numerical acquisition card (National Instrument) controlled by a software developed in the laboratory.

\section{Results and discussion}

\subsection{Characterization of the artificial patina layer}

Figure 1 shows SEM images of a copper electrode after 14 days of immersion at $50^{\circ} \mathrm{C}$ in the patination solution. The surface of the sample is covered by a heterogeneous layer of corrosion products. The formation of almost spherical outgrowths in the micrometer range (from few micrometers up to $300 \mu \mathrm{m}$ in diameter) can be distinguished mainly in the outer part of the disk. However, a closer inspection of the surface indicates that the whole sample is covered by crystals (Fig. 1b) with a needle-like structure. 
$<$ Figure $1>$

The mean thickness of the patina layer was obtained from the analysis of the cross-section of the sample, as shown in Fig. 2a. A rather homogeneous film of oxides between $8-21 \mu \mathrm{m}$ in thickness, can be distinguished on the copper surface (Fig. 2b), which is in good agreement with literature [12].

$<$ Figure $2>$

A high oxygen content has been evidenced by EDAX analysis, as shown in the cartography presented in Fig. 3a. A double-layered structure can be distinguished on this oxygen cartography, with an homogenous thin layer near the metal which is expected to be cuprite $\left(\mathrm{Cu}_{2} \mathrm{O}\right)$, and an outer thicker layer, which should correspond to copper sulphate products as it can be deduced from the comparison between oxygen (Fig. 3a) and sulphur (Fig. 3b) cartographies.

$<$ Figure 3>

Raman analysis was carried out during patina growth by extracting samples at different immersion times. Results are in good accordance with EDAX analysis. After two hours of immersion, the copper electrode is covered by a homogeneous and crystallized layer of cuprite (Spectrum I), $\mathrm{Cu}_{2} \mathrm{O}$ characterized by the presence of the band at $220 \mathrm{~cm}^{-1}$ [29]. In some places a green product is also found on the surface looking like needles on a pincushion (Fig. 4b), Spectrum II. This Raman spectrum is ascribed to brochantite $\mathrm{Cu}_{4}(\mathrm{OH})_{6} \mathrm{SO}_{4}$ with characteristic bands at $975 \mathrm{~cm}^{-1}$ and $989 \mathrm{~cm}^{-1}$ for the $v_{1}$ vibrations of $\mathrm{SO}_{4}^{2-}$ and five 
$\left(3589 \mathrm{~cm}^{-1}, 3567 \mathrm{~cm}^{-1}, 3482 \mathrm{~cm}^{-1}, 3396 \mathrm{~cm}^{-1}, 3370 \mathrm{~cm}^{-1}\right)$ of the six expected $\mathrm{OH}$ stretching vibrations $[30,31]$.

Within two days a brochantite layer begins to grow on top of the cuprite layer, and covers totally the surface after 7 days. Examination of a cross section of the sample after 14 days shows that there is no modification of the patina configuration: a thin layer of cuprite covered by a homogeneous layer of brochantite and from place to place, probably corresponding to a higher corrosion rate (and associated to the formation of brochantite within two hours) some thick, spherical outgrowths giving the Raman Spectrum III, which presents also the bands of brochantite. However the higher intensity of the band at $1088 \mathrm{~cm}^{-1}$ which belongs to antlerite $\mathrm{Cu}_{3}(\mathrm{OH})_{4} \mathrm{SO}_{4}$, another copper II hydroxysulfate, cannot excluded the presence of this compound as a minor phase of the thickest outgrowths.

$<$ Figure $4>$

\subsection{Copper corrosion in sulphate solution}

The cyclic voltammogram of copper exposed to $0.5 \mathrm{M} \mathrm{Na} \mathrm{SO}_{4}$ performed with the electrochemical microcell is presented in Fig. 5. In the anodic scan, the small anodic current registered from $-0.3 \mathrm{~V}_{\mathrm{SCE}}$ may be associated to the formation of a protective layer of cuprite on the copper surface $[2,8]$. A significant increase of current appears at $+0.4 \mathrm{~V}_{\mathrm{SCE}}$ due to the anodic oxidation of copper through the formation of cupric species without formation of $\mathrm{CuO}$ because of the little availability of oxygen in the small volume of electrolyte considered. The cathodic region of the voltammogram shows a shoulder at $-0.1 \mathrm{~V}_{\mathrm{SCE}}$ ascribed to the reduction of $\mathrm{Cu}(\mathrm{II})$ to $\mathrm{Cu}(\mathrm{I})$. A larger current peak ascribes to the reduction of $\mathrm{Cu}(\mathrm{I})$ to $\mathrm{Cu}(0)$ appears at ca $-0.4 \mathrm{~V}_{\mathrm{SCE}}[2,8]$ 
The LEIS response of the pure copper electrode after one hour of exposure to the $0.5 \mathrm{M}$ $\mathrm{Na}_{2} \mathrm{SO}_{4}$ is presented in Fig. 6a. A single capacitive loop can be distinguished in Nyquist representation of the diagram. The capacitance value estimated at $C \approx 31 \mu \mathrm{F} \cdot \mathrm{cm}^{-2}$ indicates that this time constant could be associated to the double layer capacitance in parallel with the charge transfer resistance corresponding to the copper oxidation to form the cuprite layer. It should be noticed that the contribution of a thin-oxide layer relaxation is also possible in the same frequency range, but for simplicity a single capacitance is assumed. A rough approximation of this charge transfer resistance was obtained from the diameter of the capacitive loop $\left(R_{\mathrm{ct}} \approx 5.1 \cdot 10^{3} \Omega \cdot \mathrm{cm}^{2}\right)$.

$<$ Figure 6 $>$

However, for longer immersion time (after 2 hours of exposure) two time constants are clearly evidenced: a high frequency capacitive loop and a Warburg impedance at smaller frequencies (Fig. 6b). The smaller values of capacitance $\left(C \approx 9 \mu \mathrm{F} \cdot \mathrm{cm}^{-2}\right)$ estimated for the time constant at high frequency indicates the formation of a thin layer of cuprite on the metallic surface. Slightly higher values of charge transfer resistance are estimated in this case $\left(R_{\mathrm{ct}} \approx 6.2 \cdot 10^{3}\right.$ $\Omega \cdot \mathrm{cm}^{2}$ ) in comparison with the one obtained for smaller exposure time. This indicates the formation of a protective corrosion product layer that hinders the corrosion activity. The Warburg impedance is ascribed to oxygen diffusion. The analysis of the spectrum indicates that the fraction of the exposed surface on which the oxygen reduction takes place is approximately 10 times smaller than the total dimension of the microcell. In addition, the confined environment should also diminish the oxygen concentration with time.

\subsection{Electrochemical response of patina in sulphate solution}


Even though a homogeneous composition of the patina layer was evidenced by Raman microspectroscopy (Fig. 4), a heterogenous reactivity of this material can be observed from the electrochemical characterization carried out with the electrochemical microcell. Local electrochemical measurements on different points of the artificial patina surface allow distinguishing two main areas with different electrochemical response as approximately schematized in Fig. 7. The small circle drawn on this figure corresponds to the area sensed by the microcapillary used in this work. It should be mentioned that this size can be changed using smaller or larger capillaries depending on the resolution that needs to be reached.

\section{$<$ Figure $7>$}

Cyclic voltammetry have been carried out with the electrochemical microcell at different points of both regions on the artificial patina surface. Quite different electrochemical responses have been obtained in each region of the patina surface, as shown in Figs. 8a and $8 \mathrm{~b}$, for region $\mathrm{A}$ and region $\mathrm{B}$, respectively.

\section{$<$ Figure $8>$}

In the anodic branch, the potential at which the current zero is $c a E=-0.45 \mathrm{~V}_{\mathrm{SCE}}$ is similar for both voltammograms, and is close to the one obtained in the case of bare copper. The resistive behaviour (ohmic drop) observed during the anodic scan at potentials larger than $+0.1 \mathrm{~V}_{\mathrm{SCE}}$ is ascribed to the protective character of the brochantite layer. In the cathodic scan, independently of the region of the patina investigated, the first peak observed at $-0.1 \mathrm{~V}_{\mathrm{SCE}}$ is ascribed to the oxidation / reduction couple $\mathrm{Cu}(\mathrm{II}) / \mathrm{Cu}(\mathrm{I})$. Moreover, the $\mathrm{CV}$ curves exhibits additional reduction peaks at more cathodic potentials $\left(E=-0.6 \mathrm{~V}_{\mathrm{SCE}}\right)$ than in the case of pure 
copper $\left(E=-0.4 \mathrm{~V}_{\mathrm{SCE}}\right)$. These peaks can be ascribed to the oxidation / reduction couple $\mathrm{Cu}(\mathrm{I}) / \mathrm{Cu}(0)[2,8]$. In addition, a third reduction peak at $-0.85 \mathrm{~V}_{\mathrm{SCE}}$ is observed when $\mathrm{CV}$ curves are performed on the region $\mathrm{B}$.

LEIS measurements were also carried out on different points distributed over the copper electrode with artificial patina exposed to $0.5 \mathrm{M} \mathrm{Na}_{2} \mathrm{SO}_{4}$ to evaluate the homogeneity of the patina layer. Similarly to the results obtained with CV experiments, LEIS diagrams allowed to distinguish the same two main areas (schematized in Figure 7). An example of each type of LEIS response is presented in Fig. 9.

\section{$<$ Figure 9>}

LEIS measurements on region A allow clearly to distinguish two different time constants: a capacitive loop in higher frequencies and a hemispheric diffusion process (a flattened semicircle) for the lower frequencies. The electrical parameters determined from the analysis of the HF time-constant are $C \approx 44 \mu \mathrm{F} \cdot \mathrm{cm}^{-2}$ and a charge transfer resistance $R_{\mathrm{ct}} \approx 200 \Omega \cdot \mathrm{cm}^{2}$. These values are consistent with a double layer capacitance in parallel with the charge transfer resistance due to the oxygen reduction reaction. This reaction can occur on the conducting oxides on the copper electrode, or on small defects.

Furthermore, the hemispherical diffusion observed at the smaller frequencies of Nyquist diagrams of region A confirms the hypothesis of the presence of active domains on the cuprite layer that may be seen as micro-sized electrodes, as the dimension of the microcapillary will be considerably larger than the one of these active areas. Then, LEIS results can be modelled by considering a hemispherical diffusion process on a micro-disk electrode [32]. The comparison of the experimental data with the numeric solution of hemispheric diffusion of a disk electrode gives a good correlation, as shown in Fig. 10, where the diffusion of oxygen is 
considered. In fact, the cathodic reaction of oxygen reduction is generally proposed for the mechanism of copper corrosion [33,34] and the diffusion control of oxygen has been previously reported $[7,35]$.

\section{$<$ Figure 10>}

From this numeric comparison, the diameter of the exposed area, the diffusion coefficient of oxygen and the dissolved oxygen concentration can be estimated. Values of $D_{\mathrm{O}}=2 \cdot 10^{-5} \mathrm{~cm}^{2} \cdot \mathrm{s}$ and $C_{\mathrm{O}}=1.5 \cdot 10^{-7} \mathrm{~mol} \cdot \mathrm{cm}^{-3}$ are in good agreement with value usually obtained for dissolved oxygen. Small diameters in the order of $30 \mu \mathrm{m}$ have been estimated. However, it is not possible with this approach to discriminate whether there in a single active domain or many smaller ones. Whatever the size (30 $\mu \mathrm{m}$ or smaller), such a small value is in agreement with the hemispherical diffusion response observed with the LEIS technique using a microcell technique to sense the local reactivity of the patina. Such results are usually not obtained with conventional sized electrode since the electrochemical response is an average value on the whole surface of the sample.

LEIS measurements performed in region B (Fig. 9b) exhibit a single time constant associated to a capacitive loop. The capacitance values determined in this case is $C \approx 0.35 \mu \mathrm{F} \cdot \mathrm{cm}^{-2}$, which is significantly smaller than in the case of the bare copper measurements and which confirms the presence of a thicker layer of copper oxides/sulphates on the metallic surface. The higher values of charge transfer resistance estimated from LEIS measurements on this region $\left(R_{\mathrm{ct}} \approx 30 \cdot 10^{3} \Omega \cdot \mathrm{cm}^{2}\right)$ than in the case of bare copper $\left(R_{\mathrm{ct}} \approx 6.2 \cdot 10^{3} \Omega \cdot \mathrm{cm}^{2}\right)$ indicates the protective barrier character of patina in this region of the sample. The estimation of the kinetic constant from $R_{\mathrm{ct}}$ value using Eq. 1 confirms the slow reactivity of brochantite in region $\mathrm{B}\left(k_{0}\right.$ $\left.=1 \cdot 10^{-6} \mathrm{~cm} \cdot \mathrm{s}^{-1}\right)$. 


$$
k_{0}=\frac{R \cdot T}{n^{2} \cdot F^{2} \cdot A} \cdot \frac{1}{R_{\mathrm{ct}}} \cdot C_{\infty}
$$

where $n$ is the number of electrons exchanged [7], and $C_{\infty}$ is the concentration of dissolved $\operatorname{copper}\left(C_{\infty}=1 \cdot 10^{-6} \mathrm{~mol} \cdot \mathrm{cm}^{-3}\right)$.

\section{Conclusions}

The electrochemical microcell was shown to be a powerful tool to study the local electrochemical behaviour of copper and copper patina exposed to sulphate media. It allowed performing cyclic voltammetry and electrochemical impedance measurements on various locations of the same sample. A heterogeneous electrochemical behaviour of the patina layer artificially grown on a copper electrode has been deduced from the LEIS measurements. The analysis of time constants allowed the identification of both high-protective areas and reactive small defects located in specific regions on the patina layer, whereas CV experiments enables to determine the redox couples present in the copper oxide layers. In addition, the application of the microelectrochemical cell has allowed to identify a diffusional oxygen control in these reactive spots of the patina while the diffusion of $\mathrm{Cu}$ ions has been observed during the passivation of pure copper. Such an approach allows selecting (with naked eye or with a microscope) the domain for performing local electrochemical characterization of the patina. It can be easily extended for performing local treatment on artefact without the need of a total immersion of the sample.

\section{Acknowledgements}

The authors gratefully acknowledge S. Borensztajn (UPR 15 - CNRS) for SEM and EDS analyses and D. Rose (UPR 15 - CNRS) for technical helps. 
M. M. Mennucci acknowledges her PhD grant supported by CAPES and M. Sanchez-Moreno acknowledges the Spanish Education Ministry for her pos-doctoral grant. 


\section{References}

1. Rahmouni K, Takenouti H, Hajjaji N, Srhiri A, Robbiola L (2009) Electrochim Acta $54: 5206-5215$

2. Serghini-Idrissi M, Bernard MC, Harrif FZ, Joiret S, Rahmouni K, Srhiri A, Takenouti H, Vivier V, Ziani M (2005) Electrochim Acta 50:4699-4709

3. Robbiola L, Portier R (2006) J. Cultural Heritage 7:1-12

4. Chiavari C, Bernardi E, Martini C, Passarini F, Ospitali F, Robbiola L (2010) Corros Sci 52:3002-3010

5. Marušić K, Otmačić-Ćurković H, Horvat-Kurbegović Š, Takenouti H, Stupnišek-Lisac E (2009) Electrochim Acta 54:7106-7113

6. Bernard MC, Joiret S (2009) Electrochim Acta 54:5199-5205

7. Chiavari C, Rahmouni K, Takenouti H, Joiret S, Vermaut P, Robbiola L (2007) Electrochim. Acta 52:7760-7769

8. Dermaj A, Hajjaji N, Joiret S, Rahmouni K, Srhiri A, Takenouti H, Vivier V (2007) Electrochim Acta 52:4654-4662

9. Muresan L, Varvara S, Stupnišek-Lisac E, Otmačić H, Marušić K, Horvat-Kurbegović Š, Robbiola L, Rahmouni K, Takenouti H (2007) Electrochim Acta 52:7770-7779

10. Graedel TE, Nassau K, Franey JP (1987) Corros Sci 27:639-657

11. Robbiola L, Blengino JM, Fiaud C (1998) Corros Sci 40:2083-2111

12. FitzGerald KP, Nairn J, Skennerton G, Atrens A (2006) Corros Sci 48:2480-2509.

13. Strandberg H, Atmospheric Environment (1998) 32:3511-3520

14. de Oliveira FJR, Lago DCB, Senna LF, de Miranda LRM, D'Elia E (2009) Mat Chem Phys 115:761-770

15. Gabrielli C, Ostermann E, Perrot H, Vivier V, Beitone L, Mace C (2005) Electrochem Com 7:962-968

16. Keddam M, Portail N, Trinh D, Vivier V (2009) ChemPhysChem 10:3175-3182

17. Böhni H, Suter T, Schreyer A (1995) Electrochim Acta 40:1361-1368

18. Lohrengel MM, Moehring A, Pilaski M (2000) Fresenius J Anal Chem 367:334-339

19. Böhni H, Suter T, Assi F (2000) Surf Coat Tech 130:80-86

20. Andreatta F, Lohrengel MM, Terryn H, de Wit JHW (2003) Electrochim Acta 48:3239-3247

21. Schreiber A, Schultze JW, Lohrengel MM, Kármán F, Kálmán E (2003) Electrochim Acta 51:2625-2630 
22. Krawiec H, Vignal V, Oltra R (2004) Electrochem Comm 6:655-660

23. Krawiec H, Vignal V, Akid R (2008) Electrochem Acta 53:5252-5259

24. Lohrengel MM (2004) Corros Eng Sci Tech 39:53-58

25. Oltra R, Vignal V (2007) Corros Sci 49:158-165

26. Birbilis N, Padgett BN, Buchheit RG (2005) Electrochim Acta 50:3536-3544

27. Sánchez M, Gamby J, Perrot H, Rose D, Vivier V (2010) Electrochem Comm 12:1230-1232

28. Gabrielli C, Joiret S, Keddam M, Perrot H, Portail N, Rousseau P, Vivier V (2006) J Electrochem Soc 153:B68-B74

29. Williams P F, Porto SPS (1973) Phys Rev B 8:1782-1785

30. Makreski P, Jovanovski G, Dimitrovska S (2005) Vibrational Spectrosc 39:229-239 (and references therein)

31. Schmidt M, Lutz HD (1993) Phys Chem Minerals 20:27-32

32. Fleischmann M, Pons S, Daschbach J (1991) J Electroanal Chem 317:1-26

33. Fitzgerald KP, J Nairn, Atrens A (1998) Corros Sci 40:2029-2050

34. Zelinsky AG, Ya Pirogov B, Yurjev OA (2004) Corros Sci 46:1083-1093

35. Mankowski G, Duthil JP, Giusti A (1997) Corros Sci 39:27-42 

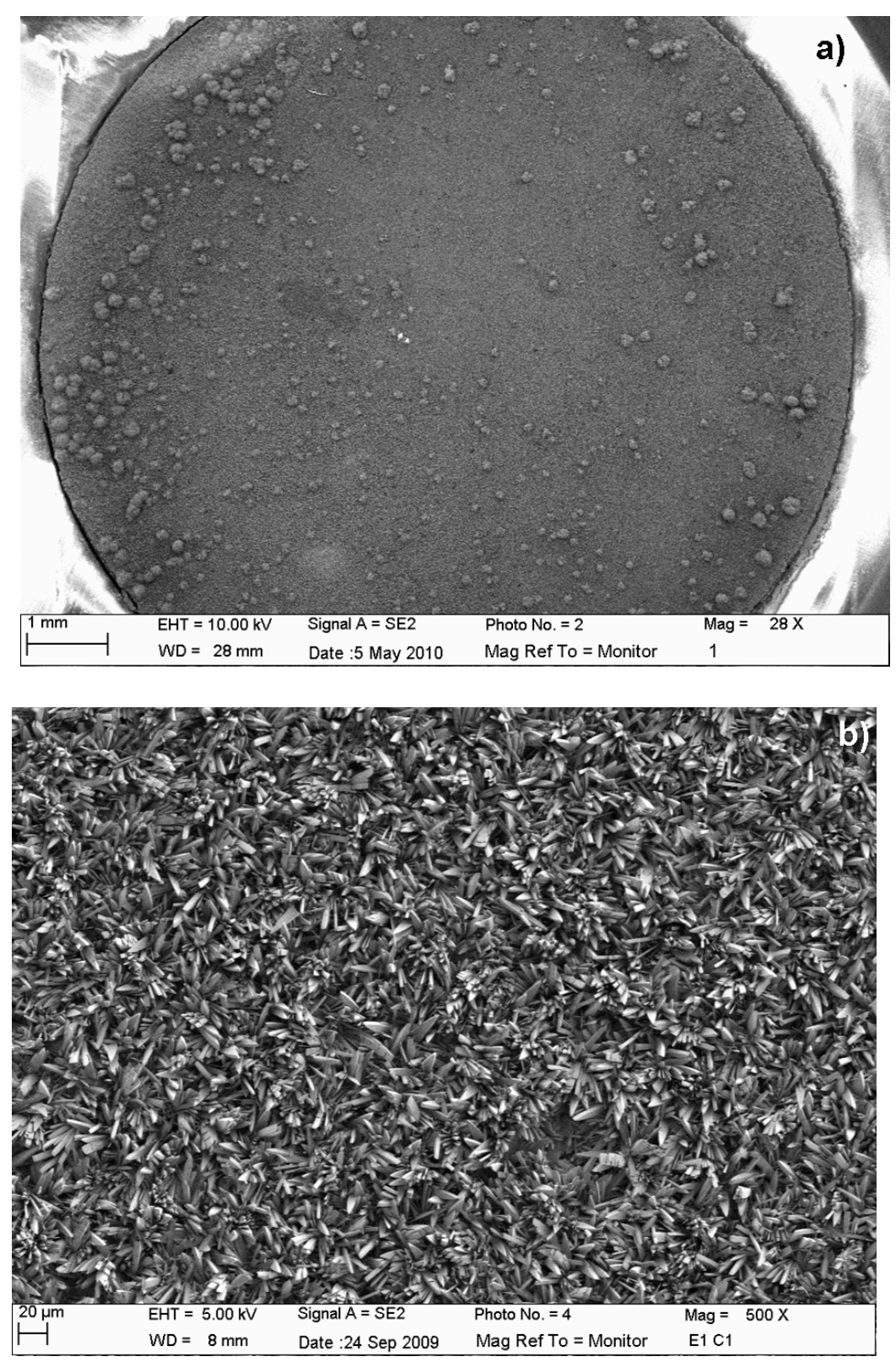

Fig. 1 SEM images of artificial copper patina: a) global view of the whole electrode surface after immersion; b) zoom on the needles forming the patina 

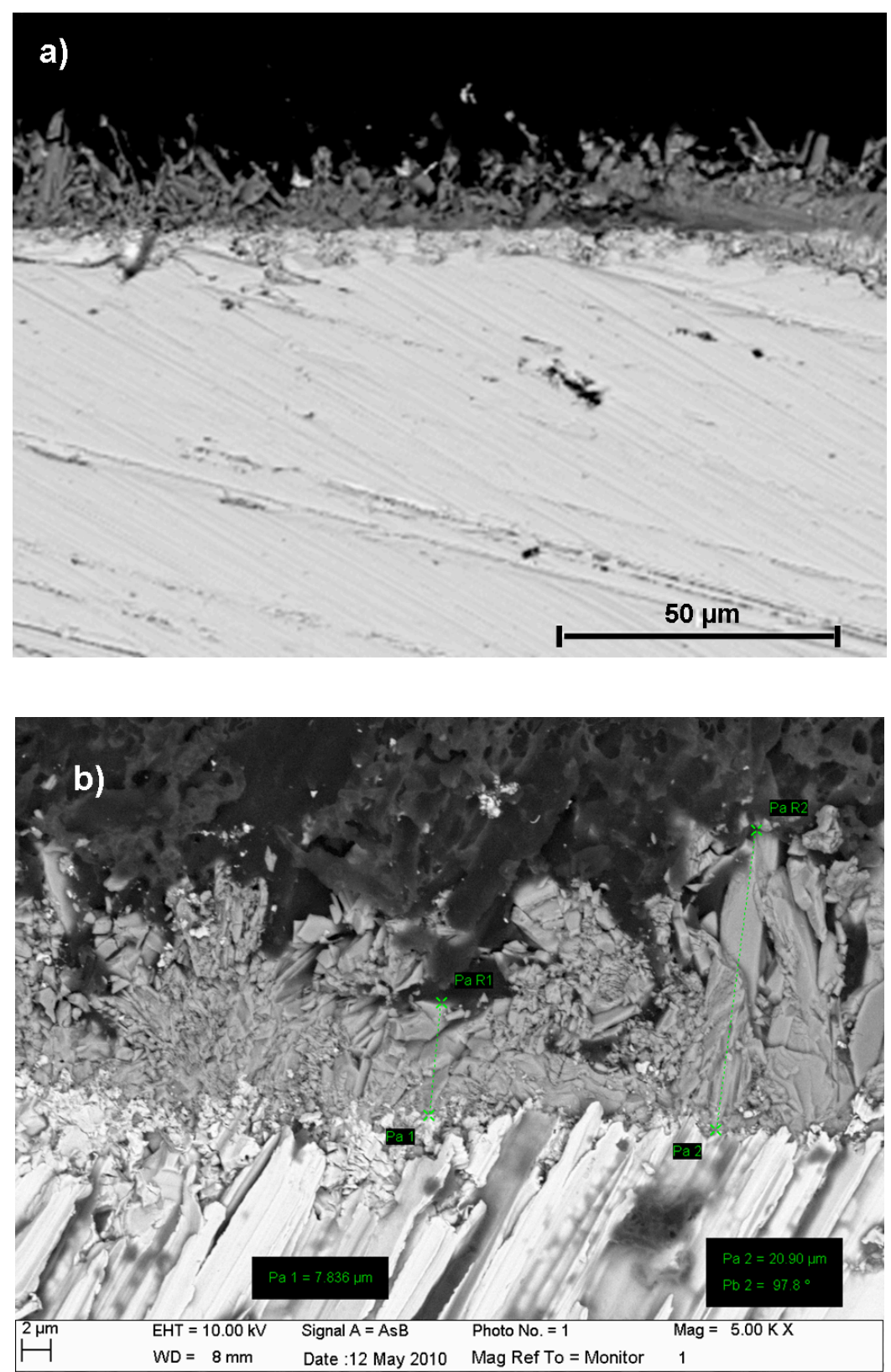

Fig. 2 SEM images of the cross-section of the sample: a) global view showing the pure copper, the patina layers, and the epoxy resin (from below to top), b) zoom for the estimation of the thickness of the patina layer 

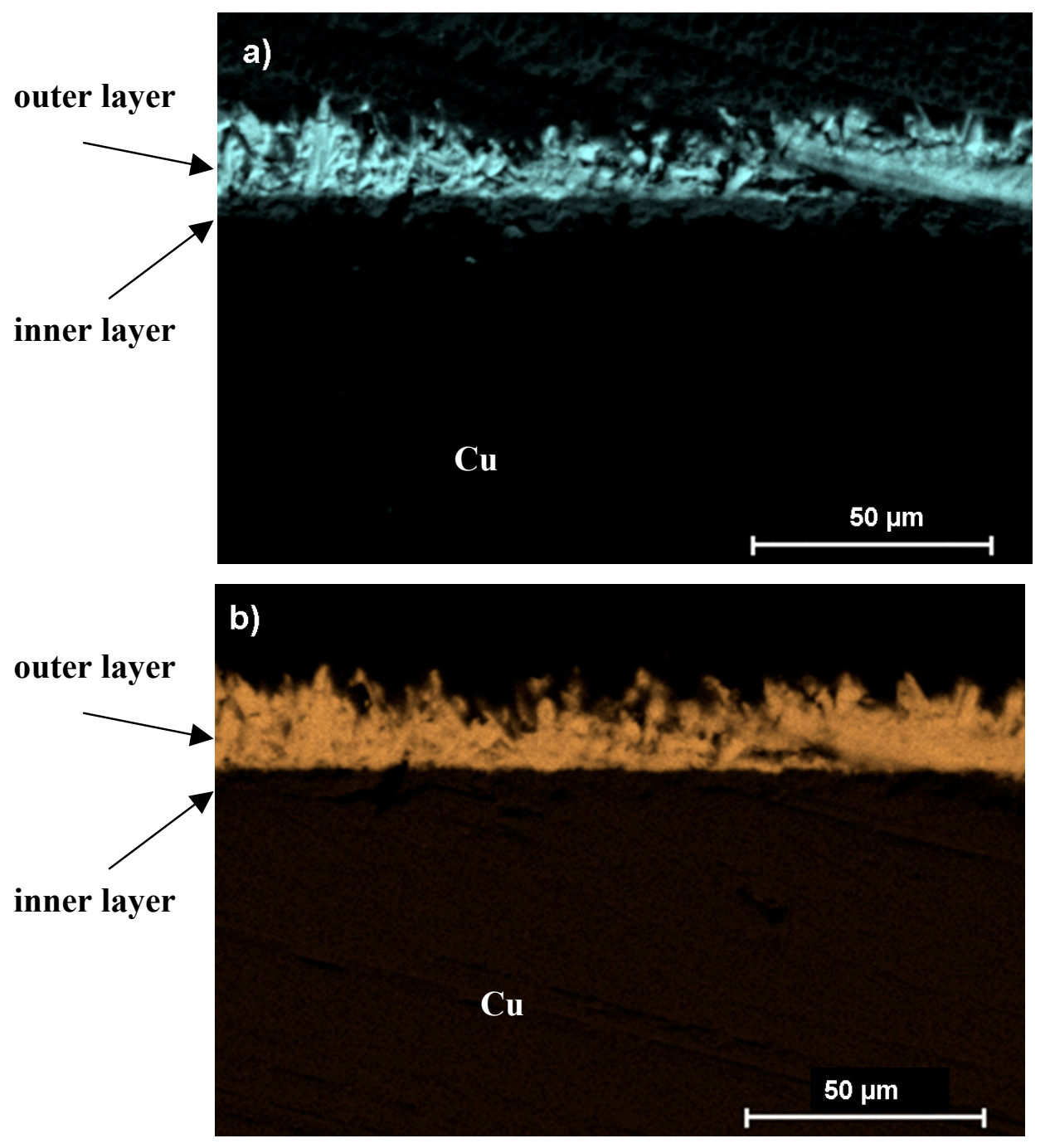

Fig. 3 EDAX analysis of the cross-section of the artificial copper patina: a) Oxygen content,

b) Sulphur content 

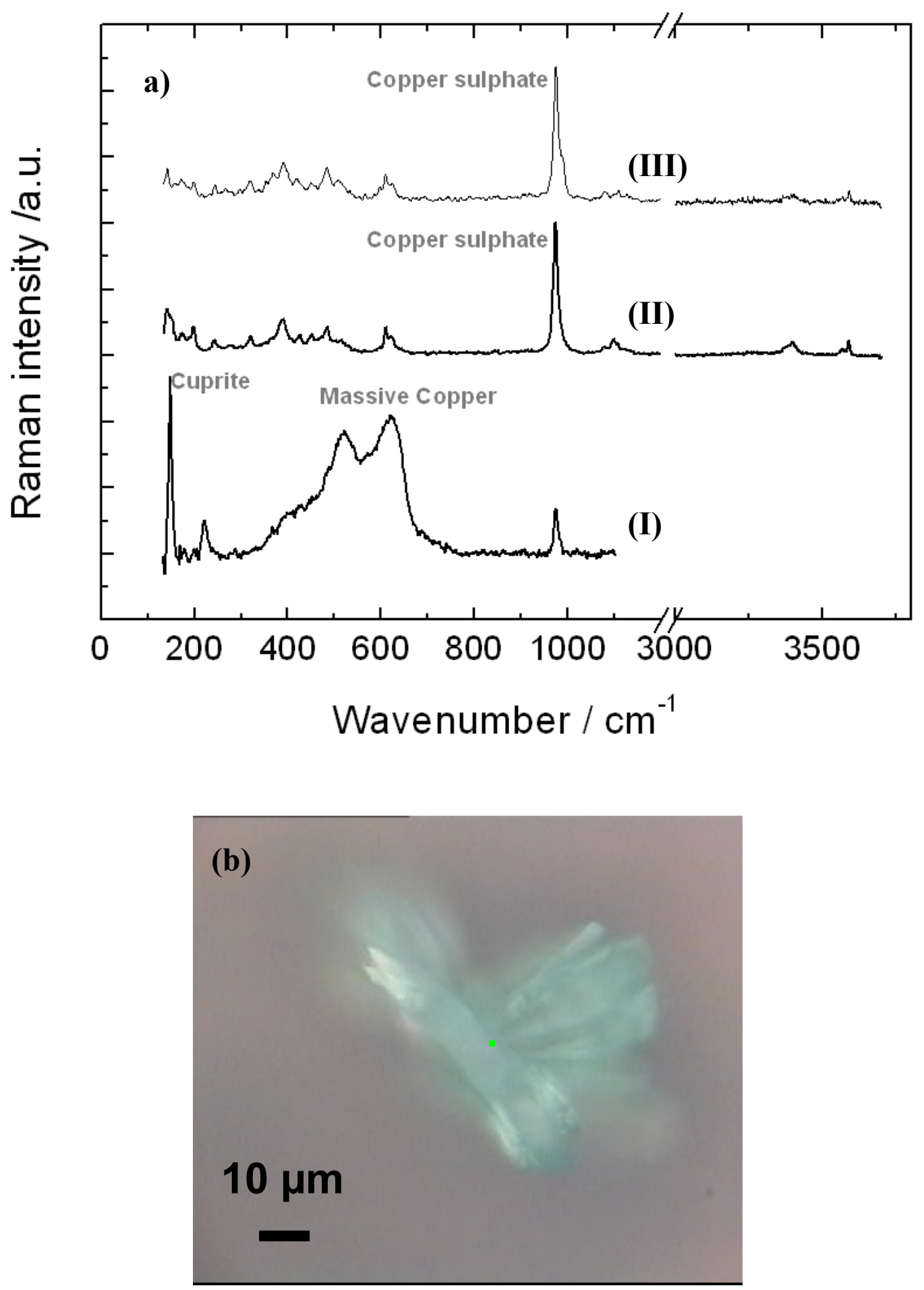

Fig. 4 (a) Raman spectra at the cross-section of artificial patina electrode: (I) near the metallic copper, (II) in the homogenous oxide layer, (III) in the spherical outgrowths; (b) Optical microscopy picture of a pincushion 


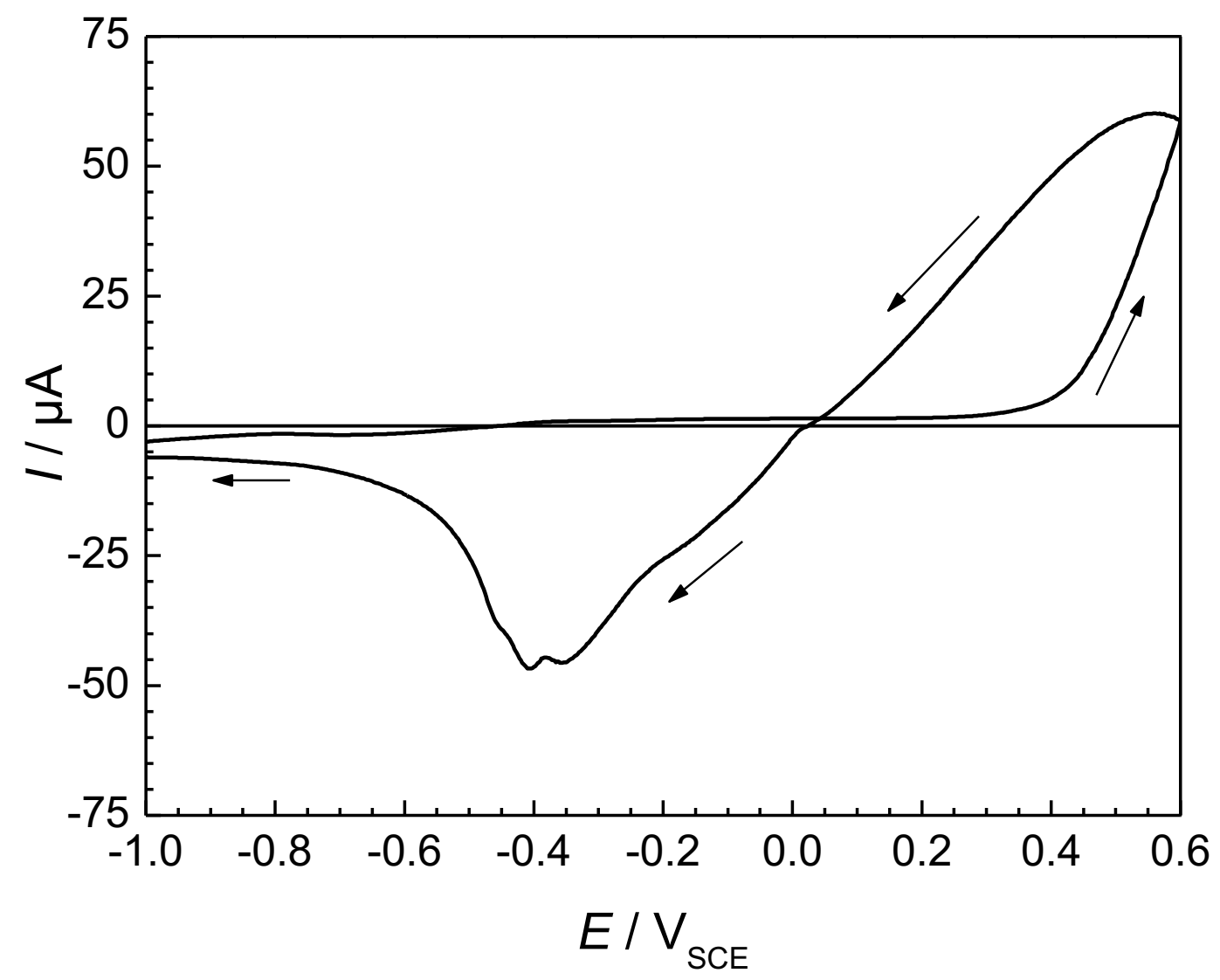

Fig. 5 Local cyclic voltammetry on bare copper exposed to a stagnant aerated $0.5 \mathrm{M} \mathrm{Na}_{2} \mathrm{SO}_{4}$ solution. $v=100 \mathrm{mVs}^{-1}$ 

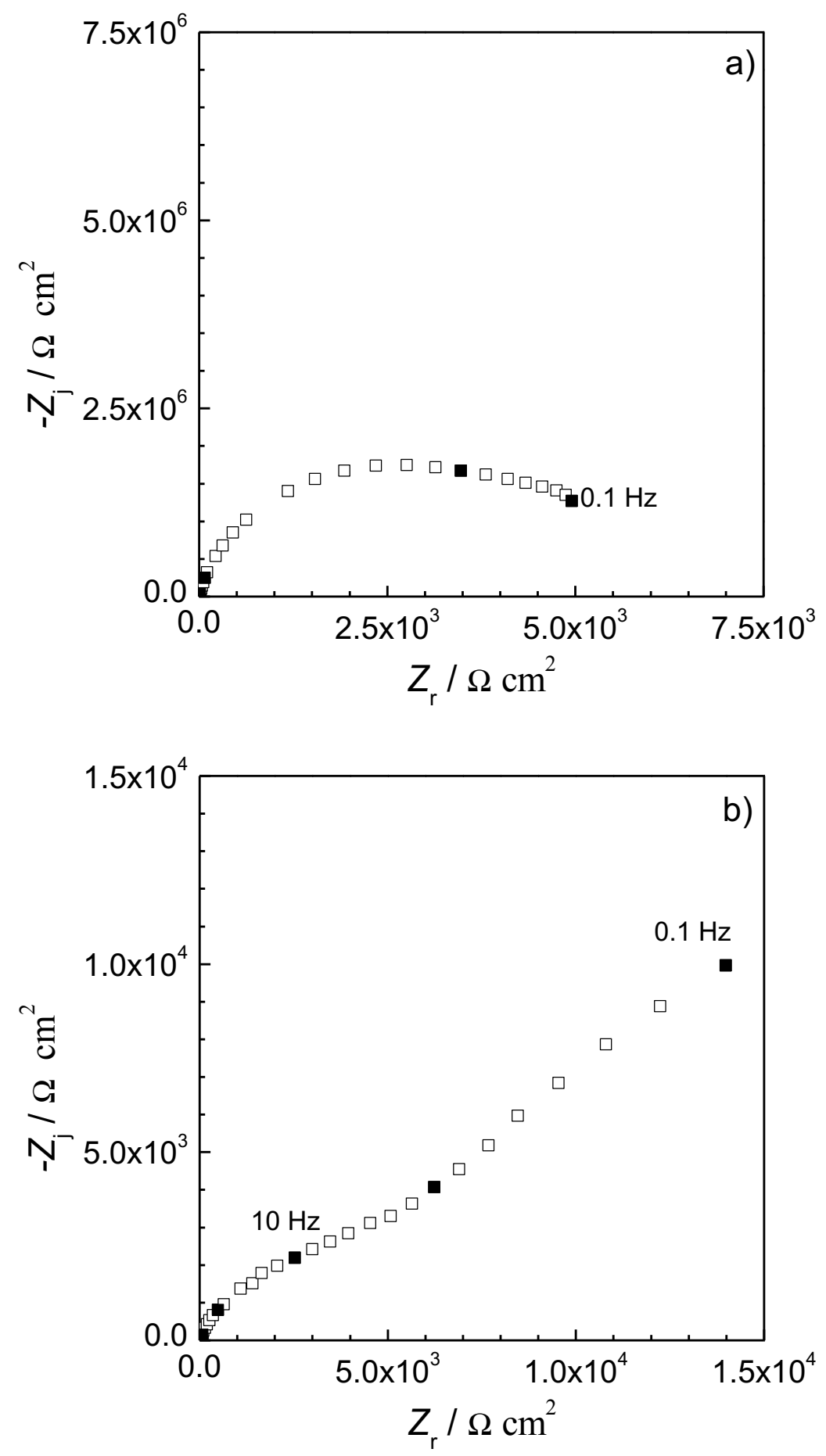

Fig. 6 LEIS measurements at the corrosion potential with the electrochemical microcell on bare copper electrode exposed to $0.5 \mathrm{M} \mathrm{Na}_{2} \mathrm{SO}_{4}$ : a) after $1 \mathrm{~h}$ of exposure, b) after $2 \mathrm{~h}$ of exposure 


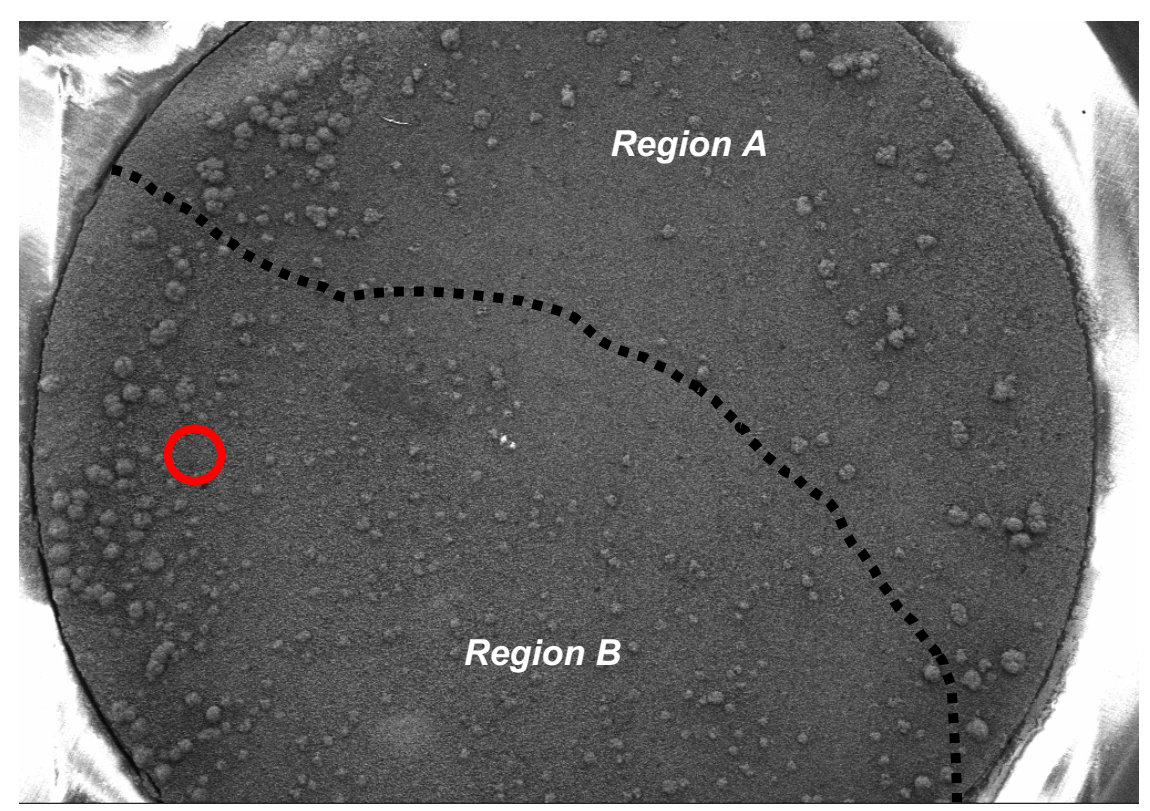

Fig. 7 Delimitation of two domains of the electrode, which exhibit a different reactivity. The red dotted circle represents the size of the microcell used in this work 

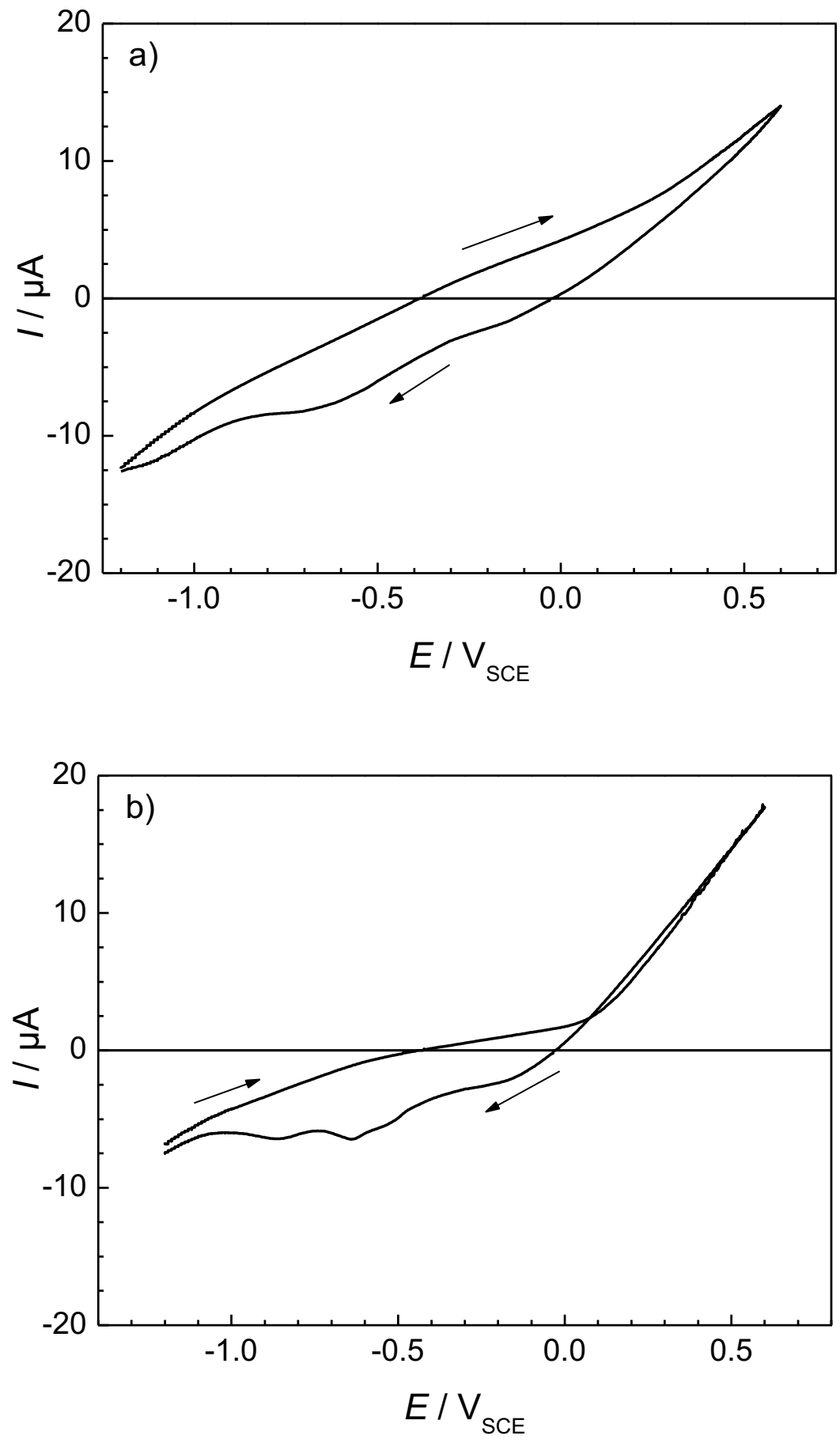

Fig. 8 Local cyclic voltammograms performed in $0.5 \mathrm{M} \mathrm{Na}_{2} \mathrm{SO}_{4}$ at $100 \mathrm{mVs}^{-1}$ on different regions of patina (see Fig. 7): a) Region A, b) Region B 

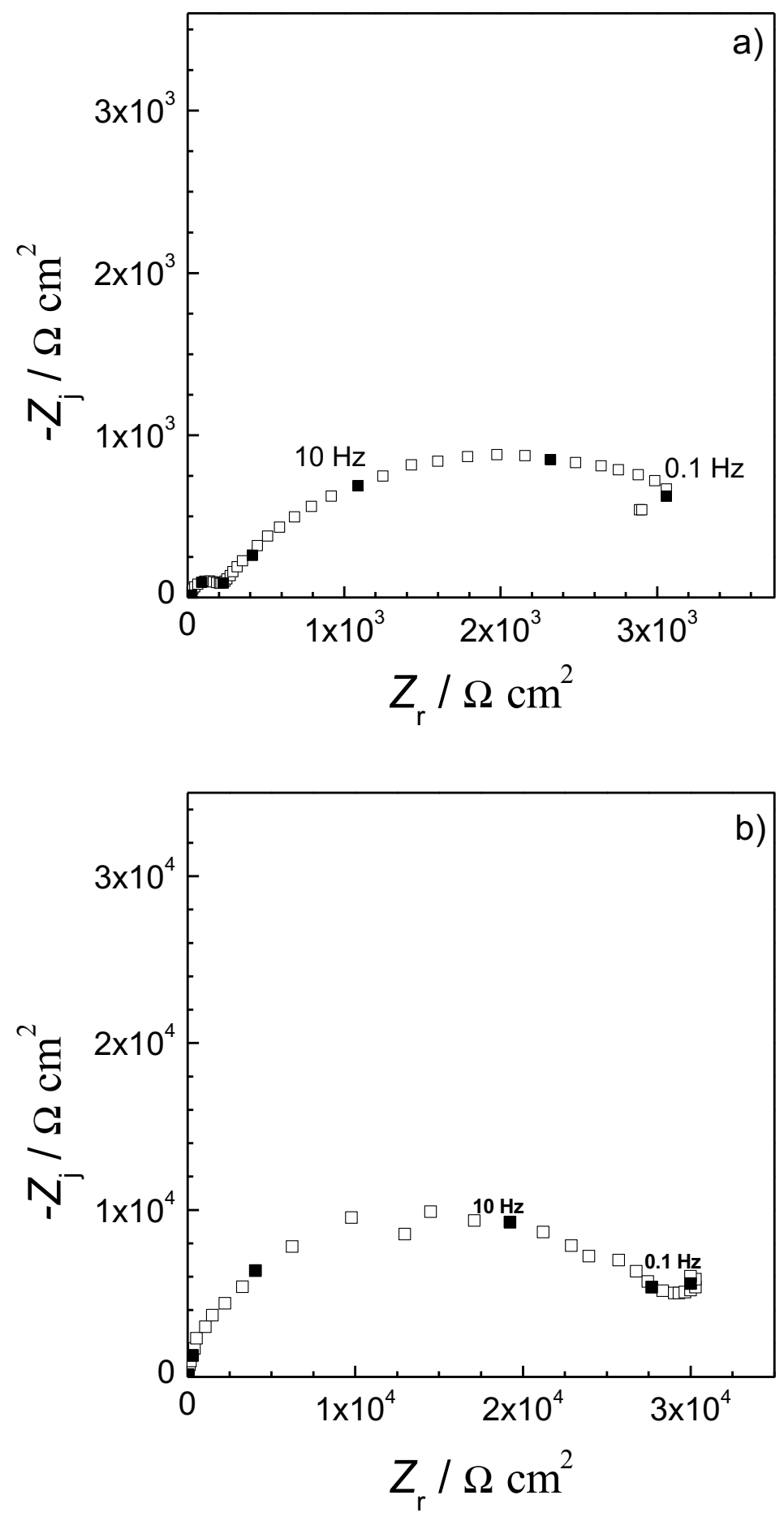

Fig. 9 LEIS measurements performed on different regions of the patina surface at the corrosion potential: a) Region A, b) Region B 


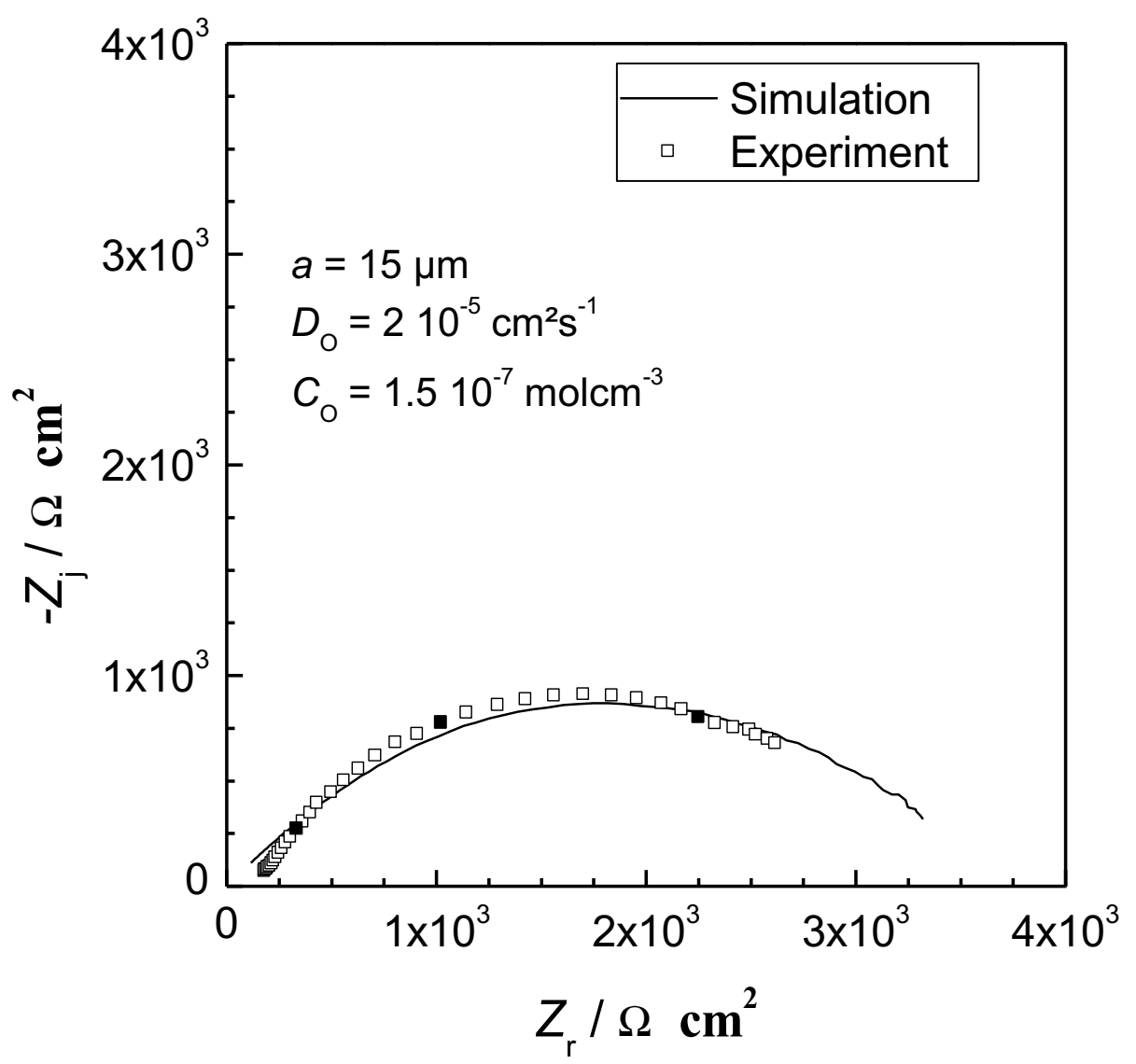

Fig. 10 Numerical simulation of the hemispherical diffusion process observed in the low frequency domain of LEIS measurements performed on the region B of sample of copper with artificial patina (Fig. 9) 